\title{
Питання психології
}

УДК 159.95

DOI: 10.33099/2617-6858-21-60-2-89-95

Кушнсрьова А. М. стариий науковий співробітник Інституту психологї̈ імені Г.С.Костюка НАПН Украӥни https://orcid.org/0000-0001-5109-4818

\section{ОСОБЛИВОСТІ КОМУНІКАТИВНОЇ КОМПЕТЕНТНОСТІ ЛІКАРЯ- КАРДІОЛОГА 3 ПАЦІНТОМ}

У статті розглядається питання емпіричного дослідження особливостей комунікативної компетентності лікаря-кардіолога з пацієнтом. На констатувальному етапі експерименту в дослідженні взяли участь медичні прачівники кардіологічного профілю різних медичних закладів. Подаються результати емпіричного дослідження.

Ключові слова: комунікація; лікар; пачієнт; якості; розвиток; ком

Вступ. Проблема комунікації стала однією 3 центральних тем, що активно обговорюються в сучасному суспільстві. Саме це обговорення, як правило, носить характер дослідження комунікації як феномена, що має певну будову та особливий механізм функціонування.

Від уміння лікаря володіти словом, від рівня його мовної культури багато в чому залежить його професійна успішність. Нові стандарти медичної освіти передбачають обов'язкове володіння фахівцем сучасними комунікативними технологіями для академічної та професійної взаємодії. У статті наводяться емпіричні данні дослідження особливостей комунікативної компетентності лікаря-кардіолога 3 пацієнтом. Дана теме є акуальною, має як практичне так і теоретичне значення.

Теоретичне підгрунття. У літературі, присвяченій етичним проблемам медицини, значна увага приділяється емоційно комунікативним аспектам медичної діяльності. А.В. Древаль зазначає, що «найважливішими психоемоційними якостями лікаря, що сприяють продуктивній бесіді 3 хворим, $\epsilon$ доброзичливість, милосердя і терпимість» [3].

«Міжособистісне спілкування - це специфічна форма контакту між людьми, що включає в себе взаємний обмін думками і почуттями 3 одночасним створенням загального фону цих думок і почуттів» [2].

Медперсонал середньої ланки протягом тривалого часу знаходиться в безпосередньому контакті з пацієнтом, тому може здійснювати як позитивний, так i негативний вплив на пацієнта. Завдання медперсоналу - максимально уникати непотрібних негативних психологічних впливів, сприяти створенню психологічного клімату, сприятливо впливає на процес одужання [1].

Проблема комунікації «лікар-пацієнт» передбачає міждисциплінарний підхід із залученням лікарів, медичних психологів, соціо-та психолінгвістів.

Проведений аналіз медичних етикодеонтологічних текстів показує, що певні аспекти мовного спілкування лікаря надзвичайно важливо враховувати i невербальні аспекти комунікації 3 пацієнтом.

Медична комунікація, ii успішність, результативність розглядається як динамічний процес 3 характерними вербальними і невербальними стратегіями i тактиками поведінки.

Сучасний пацієнт не задовольняється традиційно пасивною роллю, а проявляє прагнення до активної комунікації, бажаючи бути почутим i зрозумілим лікарем. У зв'язку 3 цим лікаря принципово важливо володіти навичками правильної побудови бесіди 3 пацієнтом, націленої на дозвіл лікувальної ситуації, не обмежуючи при цьому надій і очікувань пацієнта [5].

У зв'зку з цим лікарю важливо володіти комунікативною компетенцією на високому рівні та вміти враховувати специфіку медичного дискурсу.

Метою статті $\epsilon$ презентація емпіричного дослідження особливостей комунікативної компетентності лікарякардіолога $з$ пацієнтом.

Методи дослідження. На констатувальному етапі експерименту в дослідженні взяли участь 73 медичні працівники кардіологічного профілю різних медичних закладів. 3 них було сформовано контрольну групу (далі КГ) у складі 26 осіб 


\section{Питання психології}

та експериментальну (відповідно, 47 осіб, $\mathrm{E} \Gamma)$.

На цьому етапі була передбачено винесення суджень про рівень комунікативної компетентності працівників кардіологічного профілю за значущими в контексті нашого дослідження методиками, a саме: оцінка доброзичливості за шкалою Д. Кемпбелла; діагностика рівня емпатії I. М. Юсупова; тест В. Ряховського; опитувальник А. Карпова; експресдіагностика стійкості до конфліктів $\mathrm{H}$. Фетіскіна; методика діагностики загальної комунікативної толерантності В. В. Бойко.

Кожна із запропонованих методик розглядалася із двох позицій:

1) був здійснений аналіз результатів опитування груп, відповідно до зазначеної в кожній методиці технології опрацювання результатів. Це дозволило детально дослідити психологічні стани груп респондентів та вияснити, наскільки суттєвими є відмінності між вибірками груп КГ і ЕГ і чи коректним буде їх порівнювати;

2) кожній досліджуваній якості було поставлене у відповідність деяке абстрактне число, яке визначалось як відсоток, що складає середнє значення по групі від максимально можливого. На основі цих чисел була виведена інтегруюча величина, рівна їх середньому значенню - не відходячи від загального, ми вважали, що всі компоненти комунікативної компетентності медика $є$ рівноважливими. Можна експертним методом обрахувати вагомість кожного компонента i вивести інтегруюче значення компетентності як середньозважене, проте це виходить за межі нашого дослідження. Дана величина $\epsilon$ показовою при винесенні загальних висновків про ефективність змін, що відбуваються із компетентністю всієї групи, наприклад за іiі збільшенням можна судити про ефективність навчання.

\section{Результати дослідження.}

3 метою визначення рівня компетентності медиків кардіологічного профілю було використано 15 шкал у семи опитувальниках. Відповідно, у дослідженні кожної групи досліджуваних було поставлено деяке число К, яке визначається як:

$$
K=\frac{\sum_{i=11}^{15} K_{i}}{15}
$$

де $\mathrm{K}_{\mathrm{i}}$ показник величини рівня складової комунікативної компетентності, у відповідності до опитувальника (шкали опитування).

Для забезпечення валідності результатів експерименту необхідно довести, що відмінності між контрольною i експериментальною групою у рівні комунікативної компетентності на момент констатувального етапу експерименту $\epsilon$ несуттєвими.

Першою застосованою методикою став опитувальник з оцінки доброзичливості за шкалою Д. Кемпбелла. Оскільки шкала є прямою, то де $\mathrm{E}_{\max }-$ максимально можливий бал, що може бути отриманий за цією методикою; $\mathrm{E}_{\text {сер }}$ - отримане середнє значення.

Таблиця 1.

Дані за шкалою Д. Кемпбелла з оиінки доброзичливості

\begin{tabular}{|c|c|c|c|c|c|c|}
\hline Група & $\mathbf{E}_{\mathrm{ep}}$ & $\mathbf{E}_{\max }$ & $K_{1}$ & $\begin{array}{c}\text { Низький } \\
\text { рівень }\end{array}$ & $\begin{array}{c}\text { Середній } \\
\text { рівень }\end{array}$ & $\begin{array}{c}\text { Високий } \\
\text { рівень }\end{array}$ \\
\hline КГ & 4,24 & \multirow{2}{*}{8} & $52,00 \%$ & $38,46 \%$ & $50,0 \%$ & $11,54 \%$ \\
\hline $\mathrm{E \Gamma}$ & 4,34 & & $54,26 \%$ & $58,30 \%$ & $53,19 \%$ & $8,51 \%$ \\
\hline
\end{tabular}

Порівняємо для обох вибірок суттєвість відмінностей між ними. Оскільки кількість учасників в обох групах різна, а кількість $€$ досить невеликою (не перевищує 60 осіб), то доцільним буде застосування до порівняння непараметричного критерію U Манна-Уїтні. Для того, щоб цей критерій був застосовний iз прийнятною точністю, на його використання накладаються наступні умови [6]:

1) обсяг вибірок повинен бути не менше трьох $\left(\mathrm{n}_{1}, \mathrm{n}_{2} \geq 3\right)$; допускається існування всього двох спостережень в одній з вибірок, але при цьому в другій їх повинно бути не менше п'яти $\left(\mathrm{n}_{1}=2, \mathrm{n}_{2} \geq 5\right)$;

2) обсяг кожної з вибірок не повинен перевищувати 60.

Для цього об'єднаємо вибірки та проведемо відповідне ранжування для обох груп, визначимо вагомість кожного

Порівняємо вибірки КГ з ЕГ.

Визначимо рангову вагомість $\mathbf{P}$ для значень вибірок. Так у об'єднаній проранжованій вибірці елементи із 


\section{Питання психології}

найменшим однаковим значенням займають позиції 1 по 10, то їх рангова вага буде $\mathrm{P}=$ $(1+10) / 2=5$; елементи із значенням «3»другі за величиною, оскільки їх 18, розташуються в позиціях із 11 по 28 . Тоді їх рангова вагомість $\mathrm{P}=(11+28) / 2=19,5$ і т.д.

Порахуємо рангові суми (кожен із доданків - добуток кількості однакових значень і на їх рангову вагу):

$\mathrm{P}_{K \Gamma}=3 \cdot 5,5+7 \cdot 19,5+5 \cdot 34+5 \cdot 46,5+$ $5 \cdot 60+3 \cdot 70=945.5$

Так само розрахуємо рангову суму для $\mathrm{E} \Gamma: \mathrm{P}_{\mathrm{E} \Gamma}=1755.5$;

Визначимо емпіричні значення критерію U Манна-Уітні.

Результат: $\mathrm{U}_{\text {емп }}=594.5$;

Критичні значення $\mathrm{p} \leq 0,01: \mathrm{U}_{0,01}=408$; $\mathrm{p} \leq 0,05: \mathrm{U}_{0,05}=467$

Вісь значущості:

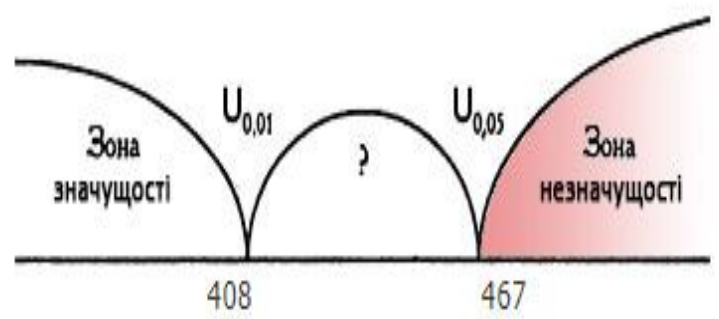

Рис 1. Значущість відмінностей проявів доброзичливості в групах КГ $і$ ЕГ.

Другими були досліджені відмінності між результатами КГ і ЕГ проведеної діагностики рівня емпатії за I. М. Юсуповим

Результати діагностики рівня емпатії за І. М. Юсуповим

\begin{tabular}{|c|c|c|c|c|c|c|c|c|}
\hline \multirow[b]{2}{*}{ Група } & \multirow[b]{2}{*}{$\mathbf{E}_{\text {cep }}$} & \multirow[b]{2}{*}{$\mathbf{E}_{\max }$} & \multirow[b]{2}{*}{$\mathbf{K}_{2}$} & \multicolumn{5}{|c|}{ Рівень } \\
\hline & & & & $\begin{array}{c}\text { Дуже } \\
\text { низький }\end{array}$ & Низький & Середній & Високий & $\begin{array}{c}\text { Дуже } \\
\text { високий }\end{array}$ \\
\hline КГ & 61,81 & 00 & $68,68 \%$ & $0,0 \%$ & $19,23 \%$ & $26,92 \%$ & $23,08 \%$ & $30,77 \%$ \\
\hline $\mathrm{E} \Gamma$ & 59,55 & 90 & $66,17 \%$ & $0,0 \%$ & $17,02 \%$ & $27,66 \%$ & $25,53 \%$ & $29,79 \%$ \\
\hline
\end{tabular}

Порівняємо вибірки КГ з ЕГ.

$\mathrm{U}_{\text {емп }}=555$ перевищує критичні значення $\mathrm{U}_{0,01}=408$ та $\mathrm{U}_{0,05}=467$.

Таким чином, відмінності у рівні емпатії в обох групах незначимі (рис 1.) i вони можуть брати участь у експерименті.

Наступним відбулося тестування за опитувальником В. Ряховського для визначення рівня комунікабельності.

Таблиця 2.

Результати діагностики рівня комунікабельності за В. Ряховським

\begin{tabular}{|c|c|c|c|c|c|c|c|c|c|c|}
\hline \multirow[b]{2}{*}{ 䄈 } & \multirow[b]{2}{*}{$\mathbf{E}_{\text {cep }}$} & \multirow[b]{2}{*}{$\mathbf{E}_{\max }$} & \multirow[b]{2}{*}{$\mathbf{K}_{3}$} & \multicolumn{7}{|c|}{ Рівень } \\
\hline & & & & 瓷 & 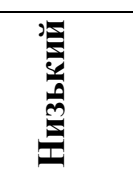 & 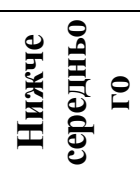 & ن & 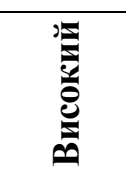 & 。 & 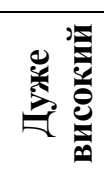 \\
\hline КГ & 15,65 & 32 & 51,09 & $7,69 \%$ & $11,54 \%$ & $15,38 \%$ & $19,23 \%$ & $23,08 \%$ & $15,38 \%$ & $7,69 \%$ \\
\hline ЕГ & 16,21 & 32 & $49,38 \%$ & $8,51 \%$ & $12,77 \%$ & $14,89 \%$ & $19,15 \%$ & $21,28 \%$ & $14,89 \%$ & $8,51 \%$ \\
\hline
\end{tabular}

Порівняємо вибірки КГ з ЕГ.

$\mathrm{U}_{\text {емп }}=589$ перевищує критичні значення $\mathrm{U}_{0,01}=408$ та $\mathrm{U}_{0,05}=467$.

Таким чином, відмінності у рівні комунікабельності в обох групах незначимі і вони можуть брати участь у експерименті.

Наступним відбулося тестування за опитувальником А. Карпова для визначення рівня рефлексивності

Дані за опитувальником А. Карпова для визначення рівня рефлексивності

\begin{tabular}{|c|c|c|c|c|c|c|}
\hline Група & $\mathbf{E}_{\text {cep }}$ & $\mathbf{E}_{\max }$ & $\mathbf{K}_{4}$ & $\begin{array}{c}\text { Низький } \\
\text { рівень }\end{array}$ & $\begin{array}{c}\text { Середній } \\
\text { рівень }\end{array}$ & $\begin{array}{c}\text { Високий } \\
\text { рівень }\end{array}$ \\
\hline КГ & 5,96 & \multirow{2}{*}{10} & $59,6 \%$ & $15,38 \%$ & $38,46 \%$ & $46,15 \%$ \\
\hline $\mathrm{E} \Gamma$ & 5,83 & & $58,3 \%$ & $14,89 \%$ & $40,43 \%$ & $44,68 \%$ \\
\hline
\end{tabular}

Порівняємо для обох вибірок суттєвість відмінностей між ними.

Порівняємо вибірки КГ з ЕГ.

$\mathrm{U}_{\text {емп }}=597.5$ перевищує критичні значення $\mathrm{U}_{0,01}=408$ та $\mathrm{U}_{0,05}=467$. комунікабельності в обох групах незначимі і вони можуть брати участь у експерименті.

Наступною була проведена експресдіагностика стійкості до конфліктів Н. Фетіскіна.

Таким чином, відмінності у рівні 


\begin{tabular}{|c|c|c|c|c|c|c|c|}
\hline & езульи & І ексn & -діагнос & ки стіu & пі до кон & ктів Н. & кіна \\
\hline Група & $\mathbf{E}_{\text {cep }}$ & $\mathbf{E}_{\max }$ & $K_{5}$ & 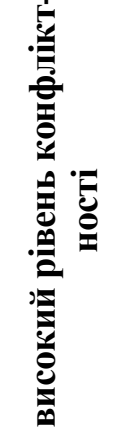 & 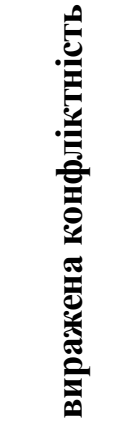 & 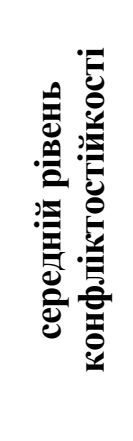 & 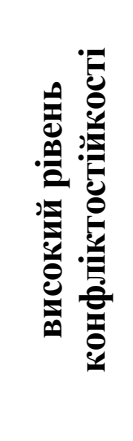 \\
\hline КГ & 36,96 & \multirow{2}{*}{50} & $73,92 \%$ & $0,00 \%$ & $11,54 \%$ & $50,00 \%$ & $38,46 \%$ \\
\hline ЕГ & 38,19 & & $76,38 \%$ & $0,00 \%$ & $4,26 \%$ & $48,94 \%$ & $46,81 \%$ \\
\hline
\end{tabular}

Порівняємо для обох вибірок суттєвість відмінностей між ними.

Порівняємо вибірки КГ з ЕГ.

$\mathrm{U}_{\text {емп }}=562.5$ перевищує критичні значення $\mathrm{U}_{0,01}=408$ та $\mathrm{U}_{0,05}=467$.

Таким чином, відмінності у рівні комунікабельності в обох групах незначимі (рис 2.5.) і вони можуть брати участь у експерименті.

Наступною була реалізована діагностика загальної комунікативної толерантності за методикою В. В. Бойко.

Ця методика містить 9 шкал для вимірювання:

Шкала 1. Неприйнятяя або нерозуміння індивідуальності іншої людини

Шкала 2. Використання себе як еталону при оцінці поведінки і способу мислення інших людей.

Шкала 3. Категоричність або консерватизм в оцінках інших людей.

Шкала 4. Невміння приховувати або згладжувати неприємні почуття при зіткненні з некомунікабельними якостями партнерів.

Шкала 5. Прагнення переробити, перевиховати партнерів.

Шкала 6. Прагнення підігнати партнера під себе, зробити його «зручним».

Шкала 7. Невміння прощати іншим помилки, незручність, ненавмисно заподіяні вам неприємності.

Шкала 8. Нетерпимість до фізичного або психічного дискомфорту, створюваному іншими людьми.

Шкала 9. Невміння пристосовуватися до характеру, звичок і бажань інших.

За кожною із шкал було винесене судження про степінь толерантності. Для визначення степені толерантності для окремої шкали ми використали методику, модернізовану до запропонованої Н.Н. Ахметгаліною та В.В. Гагай методики (автори пропонували 3 позиції інтолерантності): висока толерантність 0-5 б., середня толерантність 6-10 б., слабка толерантність 11-13 б., інтолерантність 14-15 б.

Отримані результати статистичного підрахунку опитувань були нами зведені до таблиці 6. 


\section{Питання психології}

Таблиця 6.

Результати діагностики загальної комунікативної толерантності за методикою В. В.

Бойко

\begin{tabular}{|c|c|c|c|c|c|c|c|c|c|c|c|}
\hline \multirow[t]{2}{*}{ 临 } & \multirow[t]{2}{*}{ 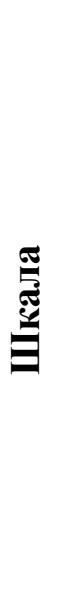 } & \multirow[t]{2}{*}{$\mathbf{E}_{\text {cep }}$} & \multirow[t]{2}{*}{$\mathbf{E}_{\max }$} & \multirow[t]{2}{*}{$K_{\overline{5.14}}$} & \multicolumn{2}{|c|}{ 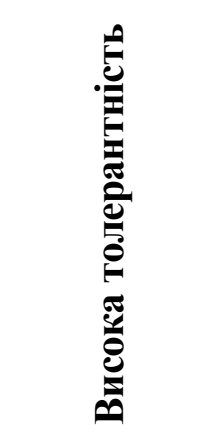 } & \multicolumn{2}{|c|}{ 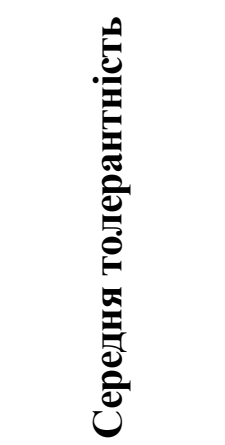 } & \multicolumn{2}{|c|}{ 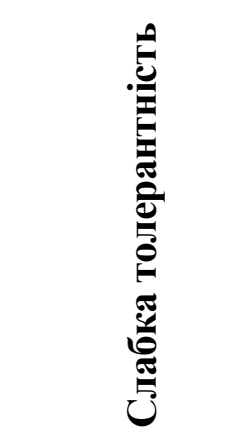 } & \multirow{2}{*}{ 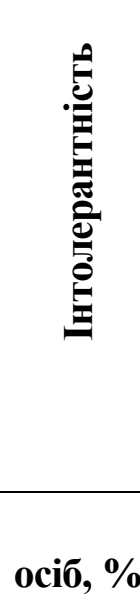 } \\
\hline & & & & & осіб & $\%$ & ociб & $\%$ & осіб & $\%$ & \\
\hline \multirow{10}{*}{ КГ } & 1 & 5,27 & \multirow{9}{*}{15} & $64,87 \%$ & 14 & 53,85 & 12 & 46,15 & 0 & 0 & 0 \\
\hline & 2 & 4,58 & & $69,49 \%$ & 15 & 57,69 & 11 & 42,31 & 0 & 0 & 0 \\
\hline & 3 & 5,27 & & $64,87 \%$ & 15 & 57,69 & 11 & 42,31 & 0 & 0 & 0 \\
\hline & 4 & 3,96 & & $73,59 \%$ & 20 & 76,92 & 6 & 23,08 & 0 & 0 & 0 \\
\hline & 5 & 4,85 & & $67,69 \%$ & 16 & 61,54 & 10 & 38,46 & 0 & 0 & 0 \\
\hline & 6 & 5,19 & & $65,38 \%$ & 17 & 65,38 & 8 & 30,77 & 1 & 3,85 & 0 \\
\hline & 7 & 5,31 & & $64,62 \%$ & 15 & 57,69 & 10 & 38,46 & 1 & 3,85 & 0 \\
\hline & 8 & 4,35 & & $71,03 \%$ & 17 & 65,38 & 9 & 34,62 & 0 & 0 & 0 \\
\hline & 9 & 4,27 & & $71,54 \%$ & 18 & 69,23 & 8 & 30,77 & 0 & 0 & 0 \\
\hline & $\sum$ & 43,04 & 135 & $68,12 \%$ & 18 & 69,23 & 8 & 30,77 & 0 & 0 & 0 \\
\hline \multirow{10}{*}{$\mathrm{E} \Gamma$} & 1 & 4,81 & \multirow{9}{*}{15} & $67,09 \%$ & 34 & 72,34 & 11 & 23,40 & 2 & 4,26 & 0 \\
\hline & 2 & 4,43 & & $70,50 \%$ & 34 & 72,34 & 13 & 27,66 & 0 & 0 & 0 \\
\hline & 3 & 4,94 & & $66,81 \%$ & 36 & 76,60 & 9 & 19,15 & 2 & 4,26 & 0 \\
\hline & 4 & 4,40 & & $70,07 \%$ & 33 & 70,21 & 14 & 29,79 & 0 & 0 & 0 \\
\hline & 5 & 4,55 & & $68,79 \%$ & 32 & 68,09 & 15 & 31,91 & 0 & 0 & 0 \\
\hline & 6 & 5,47 & & $67,80 \%$ & 32 & 68,09 & 14 & 29,79 & 1 & 2,13 & 0 \\
\hline & 7 & 4,66 & & $68,51 \%$ & 29 & 61,70 & 17 & 36,17 & 1 & 2,13 & 0 \\
\hline & 8 & 4,87 & & $66,52 \%$ & 29 & 61,70 & 17 & 36,17 & 1 & 2,13 & 0 \\
\hline & 9 & 4,28 & & $71,35 \%$ & 37 & 78,72 & 10 & 21,28 & 0 & 0 & 0 \\
\hline & $\sum$ & 42,38 & 135 & $68,61 \%$ & 33 & 70,21 & 14 & 29,79 & 0 & 0 & 0 \\
\hline
\end{tabular}

Для визначення, чи існують суттєві розбіжності між вибірками, порівняємо вибірки КГ i ЕГ для загальної комунікативної толерантності.

$\mathrm{U}_{\text {емп }}=542.5$ перевищує критичні значення $\mathrm{U}_{0,01}=408$ та $\mathrm{U}_{0,05}=467$.

Таким чином, відмінності у значеннях результатів експрес-діагностики загальної комунікативної толерантності в обох групах незначимі і вони можуть брати участь у експерименті.

Підсумовуючи

результати констатувального експерименту, зазначимо, що нам вдалося оцінити комунікативну компетентність, розглянувши іiі як сукупність компонентів - якісних характеристик особистості, відображеними в таблиці 7. 
Питання психології

Таблиця 7.

Оиінка комунікативної компетентності за ї̈ складовими

\begin{tabular}{|c|c|c|c|c|}
\hline \multirow{2}{*}{ № } & \multirow{2}{*}{ Індекс } & \multirow{2}{*}{ Шкала } & \multicolumn{2}{|c|}{ Група } \\
\hline & & & КГ & $\mathbf{E \Gamma}$ \\
\hline 1 & $K_{1}$ & Доброзичливість & $52,00 \%$ & $54,26 \%$ \\
\hline 2 & $\mathbf{K}_{2}$ & Емпатія & $68,68 \%$ & $66,17 \%$ \\
\hline 3 & $\mathbf{K}_{\mathbf{3}}$ & Комунікабельність & $51,09 \%$ & $49,38 \%$ \\
\hline 4 & $\mathbf{K}_{4}$ & Рефлексивність & $59,6 \%$ & $58,3 \%$ \\
\hline 5 & $\mathbf{K}_{5}$ & Конфліктостійкість & $73,92 \%$ & $76,38 \%$ \\
\hline 6 & $\mathbf{K}_{6}$ & Сприймання індивідуального в інших & $64,87 \%$ & $67,09 \%$ \\
\hline 7 & $\mathbf{K}_{7}$ & Сприймання іншого стилю мислення & $69,49 \%$ & $70,50 \%$ \\
\hline 8 & $\mathbf{K}_{\mathbf{8}}$ & Толерантність в оцінці інших & $64,87 \%$ & $66,81 \%$ \\
\hline 9 & $\mathbf{K}_{\mathbf{9}}$ & Вміння приховувати неприємні почуття & $73,59 \%$ & $70,07 \%$ \\
\hline 10 & $K_{10}$ & Вміння приймати людей, такими, які вони є & $67,69 \%$ & $68,79 \%$ \\
\hline 11 & $\mathbf{K}_{11}$ & Повага до особистості & $65,38 \%$ & $67,80 \%$ \\
\hline 12 & $K_{12}$ & Вміння прощати & $64,62 \%$ & $68,51 \%$ \\
\hline 13 & $\mathbf{K}_{13}$ & Терпимість до дискомфорту від спілкування & $71,03 \%$ & $66,52 \%$ \\
\hline 14 & $\mathbf{K}_{14}$ & Адаптивність & $71,54 \%$ & $71,35 \%$ \\
\hline$\sum$ & $\mathbf{K}$ & Комунікативна компетентність & $65,60 \%$ & $65,85 \%$ \\
\hline
\end{tabular}

Проведений нами констатувальний етап експерименту дозволив нам визначити поточний рівень комунікативної компетентності медиків кардіологічного профілю, який умовно склав $65,60 \%$ для контрольної і 65,85\% для експериментальної групи.

\section{Висновки та перспективи подальших} досліджень.

В ході аналізу отриманих даних було з'ясовано, що обидві відібрані нами групи (як контрольна, так і експериментальна) мають несуттєві відмінності у рівні всіх складових комунікативної компетентності а відтак можуть брати участь у експерименті, без втрати ним валідності.

Фактично за всіма показниками рівень $\epsilon$ середнім або високим. Найнижчі значення має комунікабельність $\quad(51,09 \%$ для контрольної і 49,38\% для експериментальної групи), а найвищі - конфліктостійкість, відповідно 73,92\% для контрольної і 76,38\% для експериментальної групи.

Перевіримо висунуту нами гіпотезу про те, що впровадження науково-обгрунтованої моделі розвитку комунікативних якостей медичного працівника підвищить рівень комунікативної компетентності медичних працівників, а отже й ефективність взаємодії в діаді «медичний працівник - пацієнт кардіологічного профілю».

Перспективу подальших досліджень вбачаємо у проведенні замірів результативності впровадження моделі розвитку комунікативних якостей медичного працівника в діаді «медичний працівник - пацієнт кардіологічного профілю».

Список використаних джерел:

1. Барсукова, М.И., Дорогойкин, Д.Л., \& Кочеткова, Т.В. (2016). Проблема коммуникации по линии «Врач - пачиент», 1,34-56.

URL: https://cyberleninka.ru/article/n/problema-kommunikatsii-po-linii-vrach-patsient.

2. Гаврилов, В.Е. (1986). Модульный подход $к$ психологической классификаиии профессий. Совершенствование профориентачии и профотбора молодежси на рабочие профессии. Ленинград: Сига.

3. Древаль, Александр (2016). Эндокринология. Руководство для врачей. Общие вопроси диагностики болезней. Клиническая ендокринология. Москва:«Гэотар-Медиа».

4. Дымнова, Л.В., \& Качимова, В.И. Специфика коммуникащии в медииинском добровольчестве. Моска: Сигма https:/xn---ctbhcbtapdmikb4a2a0m.xn--p1ai/wp-content/uploads/2018/12/Metodicheskierekomendatsii--Spetsifika-kommunikatsii--.pdf

5. Литвинчук, Л.М. (2020). Невротичність як предиктор формування психічних порушень осіб 3 соматичною патологією. Вісник Київського інституту бізнесу та технологій. Київ, № 2(44), 56-64.

6. Титкова, Л.С. (2002). Математические методы в психологии: учебное пособие. Владивосток: ТИДОТ ДВГУ. 


\section{Питання психології}

\section{References:}

1. Barsukova, M.Y., Dorohoikyn, D.L., \& Kochetkova, T.V. (2016). Problema kommunykatsyy po lynyy «Vrach - patsyent» [The problem of communication along the line "Doctor - patient"], 1, 34-56. (in Russian).

2. Havrylov, V.E. (1986). Modulnyi podkhod $k$ psykholohycheskoi klassyfykatsyy professyi. Sovershenstvovanye proforyentatsyy y profotbora molodezhy na rabochye professyy. [A modular approach to the psychological classification of professions. Improvement of vocational guidance and vocational selection of young people for working professions]. Lenynhrad: Syha. (in Russian).

3. Dreval, Aleksandr (2016). Fndokrynolohyia. Rukovodstvo dlia vrachei. Obshchye voprosy dyahnostyky boleznei. Klynycheskaia endokrynolohyia. [Endocrinology. A guide for doctors. General questions about the diagnosis of diseases. Clinical endocrinology]. Moskva:«Hэotar-Medya». (in Russian).

4. Dumnova, L.V., \& Kachymova, V.Y. Spetsyfyka kommunykatsyy v medytsynskom dobrovolchestve. Moska: Syhma https://xn----ctbhcbtapdmikb4a2a0m.xn--plai/wp-content/uploads/2018/12/Metodicheskierekomendatsii---Spetsifika-kommunikatsii-.pdf4.

5. Lytvynchuk, L.M. (2020). Nevrotychnist yak predyktor formuvannia psykhichnykh porushen osib z somatychnoiu patolohiieiu ГNeuroticism as a predictor of the formation of mental disorders in people with somatic pathology]. Visnyk Kyivskoho instytutu biznesu ta tekhnolohii. Kyiv, 2(44), 56-64.

https:/herald.kibit.edu.ua/index.php/visnyk/article/view/101/90 (in Ukrainian).

6. Tytkova, L.S. (2002). Matematycheskye metody v psykholohyy: uchebnoe posobye [Mathematical methods in psychology: a textbook]. Vladyvostok: TYDOT DVHU. (in Russian).

\section{Резюме \\ Кушнсрьова А. Н. старший научный сотрудник \\ Института психологии имени Костюка АПН Украинь \\ ОСОБЕННОСТИ КОММУНИКАТИВНОЙ КОМПЕТЕНТНОСТИ ВРАЧА-КАРДИОЛОГА С ПАЦИЕНТОМ}

В статье рассматривается вопрос эмпирического исследования особенностей коммуникативной компетентности врача-кардиолога с пачиентом. На констатирующем этапе эксперимента в исследовании приняли участие медицинские работники кардиологического профиля различных медичинских учрељдений. Представлено результаты эмпирического исследования.

Ключевье слова: коммуникация; врач; пащиент; качества; развитие; коммуникативная компетентность.

\section{Summary \\ Kushnierova A. Senior Researcher, Institute of Psychology GS Kostyuk NAPN Ukraine}

FEATURES OF COMMUNICATIVE COMPETENCE OF A CARDIOLOGIST WITH A PATIENT

The problem of communication has become one of the central topics that are actively discussed in modern society. It is this discussion, as a rule, has the character of the study of communication as a phenomenon that has a certain structure and a special mechanism of functioning.

His professional success largely depends on the doctor's ability to speak, the level of his language culture. The new standards of medical education provide for the mandatory possession of modern communication technologies for academic and professional interaction. The article presents empirical data of research of features of communicative competence of the cardiologist with the patient. This topic is current, has both practical and theoretical significance.

The problem of "doctor-patient" communication involves an interdisciplinary approach involving doctors, medical psychologists, socio-psycholinguists.

The analysis of medical ethical and deontological texts shows that certain aspects of the doctor's verbal communication are extremely important to take into account the non-verbal aspects of communication with the patient.

The article considers the question of empirical research of features of communicative competence of the cardiologist with the patient. At the ascertaining stage of the experiment, medical workers of cardiological profile of various medical institutions took part in the research. The article presents the results of empirical research.

During the analysis of the obtained data it was found that both selected groups (both control and experimental have insignificant differences in the level of all components of communicative competence and therefore can participate in the experiment without losing validity.

In fact, for all indicators, the level is medium or high. The lowest values are sociability, and the highest - conflict resistance for the experimental group.

Let's test our hypothesis that the introduction of a scientifically sound model of development of communicative qualities of a medical worker will increase the level of communicative competence of medical workers, and hence the effectiveness of interaction in the dyad "medical worker - patient of cardiological profile".

We see the prospect of further research in measuring the effectiveness of the implementation of the model of development of communicative qualities of a medical worker in the dyad "medical worker - a patient with a cardiac profile."

Keywords: communication; doctor; patient; quality; development; communicative competence.

Recelved/Поступила: 19.03.21. 